\title{
Violating the Maxims of Quality and Quantity on the 'Demo Sabun' Sketch of Extravaganza Situation Comedy TV
}

\author{
Setia Rini \\ English Department of Educational Faculty \\ State Islamic Studies Institute (STAIN) Salatiga \\ Jl. Tentara Pelajar no. 2 Salatiga, Central Java, Indonesia
}

\begin{abstract}
This study focuses on analyzing the violation of maxims as proposed by Grice in his cooperative principles. The subject of the study is on one of TV sitcoms broadcasted by one of the private owned TV station in Indonesia. The writer collected the data by transcribing the dialogues among the comedian in one sketch. In this modern era there are many busy people who need such kind of entertainment to lead them release their fatigue after having a day work. This situation invites some creative people to produce humor which is then packaged in the form situation comedy. These sitcoms can be broadcasted in many television stations now. In creating such funny expressions, there must be the violation on some maxims. By violating the maxims; the humorous verbal interaction can be achieved. The writer found that there are two types of violation on maxims of quality and quantity in one of the extravaganza's sketches.
\end{abstract}

Key words: Violation, Maxims, Humor

\begin{abstract}
Abstrak
Penelitian ini berfokus pada analisis pelanggaran maksim-maksim sesuai dengan teori yang dipaparkan oleh Grice dalam prinsip-prinsip kooperatifnya. Subyek dalam penelitian ini adalah salah satu sitkom yang ditayangkan di salah satu saluran televisi swasta di Indonesia. Penulis mengumpulkan data dengan membuat traskip percakapan yang dilakukan oleh para komedian dalam satu sketsa. Pada era modern seperti saat ini, dimana banyak orang yang terlalu sibuk dengan pekerjaan mereka, sangat membutuhkan hiburan yang dapat membantu melepaskan kepenatan setelah seharian bekerja. Situasi seperti ini akhirnya menarik orang-orang yang kreatif untuk membuat lawakan yang akhirnya dikemas dalam bentuk situasi komedi atau sitkom. Dan sekarang sitkom-sitkom tersebut akhirnya dapat ditayangkan di beberapa
\end{abstract}


stasiun televisi. Kemudian untuk membentuk beberapa ekspresi-ekspresi yang lucu, dalam adegan harus dilakukan pelanggaran pada beberapa maksim. Dengan melanggar maksim-maksim tersebut, akan diperoleh interaksi verbal yang humoris. Penulis menemukan bahwa ada dua jenis pelanggaran maksim-maksim tersebut, yakni pelanggaran pada maksim kualitas dan maksim kuantitas pada salah satu sketsa dalam acara Extravaganza.

Kata Kunci: Pelanggaran, Maxim, Humor

\section{Introduction}

In every day life, people need to get a kind of entertainment to refresh their mind after having business in whole weeks. People need the topic of humor to make them laugh a lot and feel happy. Some of the TV stations in Indonesia present the programs in the form of various situation comedies TV. There are many situation comedies on some TV stations such as Office Boy for RCTI, Abdel dan Temon for Global TV, Coffee Bean Show for Metro TV. One of the TV broadcasters is TRANS TV; it broadcasts the situation comedies or humor genres such as Bajaj Bajuri, Ngelenong Nyok, Extravaganza ABG, Komedi Betawi, Suami-Suami Takut Istri, Sketsa Ajah and Extravaganza that are able to entertain people in their spare time. Extravaganza situation comedy TV is broadcasted in the form of series of sketches for each episode. The extravaganza sitcom program is mostly viewed by the TV viewers because the contents of sketches are very funny and varied and deals with the current issues. It is played by some talented comedians like Virnie Ismail, Tora Sudiro, Ronny Dozer, Tike Priyatna Kusumah, Sogi Indra Duaja, Indra Birowo, Ronald Surapraja, Mike Amalia, TJ, Aming, Luna Maya, Katty Sharon, Omesh and some of the new comers. They entertain lots of audiences on Saturday evening and Monday evening at 7 to $9 \mathrm{pm}$ but then it is replaced to be broadcasted at 8 to $10 \mathrm{pm}$ with full of intellectual ideas which sometimes also inserting some taboo ideas. In each 
episode, it consists of many sketches and presented in ten minutes then it is broken by the commercial breaks. After presenting the sketches, the other segment is Bincang-Bincang Extravaganza, Sinden Gosip, and Extra News. Bincang - bincang Extravaganza deals with the interview with the guest star and the imitation of the guest star performed by one of the comedians for example if the guest star's name is Dewi Persik, so the imitation of the guest star's name is Dewi Bersisik and so on. In Sinden Gosip, two female of the extravaganza's comedians called Tike, Tije Watije dress like sinden (a Javanese traditional singer) and one male comedian called Tora Sudiro who must perform like a female dresses in Indonesian traditional costumes represents the involving of the tribes all over Indonesia. In Extra News, they perform as news presenters and present the funny news by giving the different pictures for the news presented.

We know that such a kind of genre is so popular among us but studies of television comedy are rare. According to Wikipedia, the free encyclopedia, a situation comedy is a genre of comedy programs which originated in radio, but today they are found almost exclusive on common television as one of its dominant narrative forms. Sitcoms usually consist of recurring characters in environment such as a home, a workplace and generally include laugh tracks or studio audiences. Some TV comedies have different comedy format, a sketch comedy, which generally featured new characters and situations each outing, or the humorous monologue or dialogue which did not feature character. Often these other formats were presented within a variety format mixed with musical performances. As we know that the humor in sitcoms varies, it is usually character driven, which result in running gags during the series. The extravaganza situation comedy is a sketch comedy filled by some humorous dialogues. It is also featured by the characters for different 
situations and always makes the audiences laugh at them a lot due to the jokes they present.

What make the audiences laugh at them a lot is not only a matter of the jokes but also of the costumes they wear for the appropriate situations and body language they act when they perform for certain characters which are followed by musical performances. Most of the sketches presented in the sitcoms must be prepared as well as possible. In the back of the stage they make the preparation by practicing the scripts altogether. But there is the one who is in charge of writing the scripts or we can call him/her a scriptwriter. In creating the scripts that deal with social reality, the scriptwriter must be able to violate the maxim. As we know that the scripts for humorous utterances can also be interpreted from pragmatics angle by employing Grice's Cooperative Principle.

Pragmatics is the branch of linguistics which studies how speakers use language to achieve their goals and how hearers interpret the meaning the speaker wishes to convey (Aitchison 2003:104). He added that a conversation depends not only on the speaker, who is trying to deliver a message, but also on the hearer, who draws a conclusion from the implication of the utterance, depending on the context in which it occurs. In contrast to syntax and semantics, pragmatics focuses on human cooperation and knowledge instead of on linguistic meaning and structure only. Semantics, which concentrates on the study of meaning of the lexical item and lexical structure, is the precursor to pragmatics, which focuses on the intended meaning dependent on the context (Aitchison 2003:88104).

The scripts for the extravaganza sitcoms are also written in the form of conversation which consists of many utterances presented for each sketch which is then interpreted by the audiences based on the contexts and mostly create laughter. In order to show what goes on in conversation, Grice 
introduced four conversational maxims. A speaker might fail to observe a maxim but still get the intended meaning through to the hearer. Failing to observe a maxim is often referred to as 'breaking a maxim' or violating the maxims. In sitcoms these maxims are constantly broken to create humor. The writer focuses on the violation of maxim quality and quantity that can create humorous situation in verbal interaction. Dealing the description above, there is a simple problem formulation in a simple question as follows; what kind of maxims violated in the extravaganza situation comedy on sketches 'Demo Sabun'? and how the maxims are violated in the sketch?

\section{Definition of humor}

The definition of humor is ultimately depends on the purpose for which it is used. As Attardo (1994:4) points out, in the field of literary criticism, for example, there is a need for a fine-grained categorization, whereas linguists have often been happy with broader definitions, arguing that whatever evokes laughter or is felt to be funny is humor, i.e. that humor can be deduced from its effect. However, laughter as such is not necessarily a condition for humor. Many views of humor are based merely on circular statements. For example humor is based on the will to laugh. Humor is based on what is funny. We laugh at what is funny. Humor is based on the ludicrous. In other words, humor is whatever is intended to be funny, even if it might not always be perceived or interpreted as such. This definition does have its problems, since measuring intention is hardly easy; yet it is useful because it accounts for humor as a fundamentally social phenomenon as well as one whose manifestations can vary greatly in different cultures. That is why most TV channels broadcast such kind of program for the purpose of entertaining people which stimulate them to laugh. It can be scrutinized that there are no basic differences of humor from different culture, that all the things and 
actions performed by some humorists can be perceived as funny will result in laugh.

\section{Cooperative principle}

In order to explain how hearers interpret the utterance, Grice introduced Cooperative Principle (CP). The CP states: "Make your contribution such as is required, at the stage at which it occurs, by the accepted purpose or direction of the talk exchange in which you are engaged" (Grundy 1995:37). According to this principle, both speaker and hearer converse with the willingness to deliver and interpret a message. The speaker and hearer cooperate and that is why they communicate efficiently (Thomas 1995:63). Based on the definition above it means that when people converse, they need to cooperate with the ideas and the message so that there will be no miss communication among the speaker and the hearer. For example, the communication among the speakers in TV sitcoms can be accepted by the hearer. In this case the TV viewers, they can accept the utterances produced by the comedians. It means that there cooperative principles occur, and it is responded by laughing at what they hear and see.

\section{Conversational maxims}

In order to illustrate how we interpret meaning, Grice presented, in addition to the Cooperative Principle, four conversational maxims to show how we communicate effectively in the light of certain rules. He formulates the principle and its maxims in Logic and Conversation (1975) as follows: make your contribution such as is required at the stage at which it occurs, by the accepted purpose or direction of the talk exchange in which you are engaged. So, when we communicate with other people, we must deliver the message as it is required based on the context so that we can interpret and understand the implicatures of an utterance as effective as possible. From 
what has been stated by Grice, it can be formulated, in communication whatever messages are delivered, it must follow the path of contexts, so that the messages can be understood based on their observation toward those related maxims. We can communicate each other by following certain rules as formulated by Grice called the conversational maxims as described below:

\section{Maxim of quantity}

Maxim of quantity requires the speaker to give the right amount of information when s/he speaks, which means not to be too brief or to give more information than the situation requires. Consider the example when someone asks, by way of greeting, "How are you doing today"?, and then a speaker says: "I'm feeling good today, but yesterday I was very ill, and the day before that, even worse",. In the greeting context the utterance contains too much information and the maxim is not being observed. The speaker fails observing the maxim. In short, first, when we make the conversation, make our contributions as informative as is required (for the current purpose of the exchange) and second, do not make our contributions more or less informative than is required.

\section{Maxim of quality}

The maxim of quality is a matter of giving the right information. The speaker says nothing that s/he knows to be false or for which s/he lacks sufficient evidence (Thomas 1995:67). The other maxims are dependent on this maxim since, if a speaker does not convey the truth then the utterance is false, even if the right amount of information is given or the speaker is clear and orderly when speaking (Finegan 1994:341). An example of nonobservance is: "you look good with your new haircut" when one actually believes the opposite. The statement is then an untruth, the speaker fails to 
observe the maxim in order to be polite. In short, (1) not say what they believe to be false, (2) do not say that for which you lack adequate evidence.

\section{Maxim of relevance}

The maxim of relevance requires the speaker to be relevant to the context and situation in which the utterance occurs (Thomas 1995:70). For instance, a speaker should not say "I am on the phone" when someone asks if s/he wants dinner. Here the utterance meaning is irrelevant and the speaker fails to observe the maxim. In short, be relevant. In other case, most comedians violate this maxim also. Again, the purpose is to make it funny and the audiences will laugh at what they produced.

\section{Maxim of manner}

The maxim of manner is a matter of being clear and orderly when conversing. The speaker describes things in the order in which they occurred and avoids ambiguity and obscurity (Thomas 1995:64). A speaker fails to observe the maxim of manner when s/he says "I went to bed and got undressed" when, of course, s/he undressed first and then went to bed. In short, (1) avoid obscurity of expression, (2) avoid ambiguity, (3) be brief, (4) be orderly

People are supposed to follow this cooperative principle and its maxims in order to arrive at meaningful verbal exchanges in their communication in an effective way.

\section{Violation of the four maxims and achievement of humor}

Grice (1975) stated that the sense of humor achieved by violating the maxims of the cooperative principle deliberately. But different from dull and uninteresting conversation, humor is the embodiment of intelligence. One of its conspicuous features is funny and comical. Humor shows a brisk and 
happy attitude and an optimistic belief, as well profound meaning. Another feature of humor is implicit. It doesn't show the opinions, comments, suggestion directly. Through all various techniques of language, it exposes the absurd and suspicious of the problem, which attracts people to reasoning, deduction. The example below is going to analyze the humor caused by violating cooperative principles of conversation in detail. Some examples together with brief analyses on violating each maxim of $\mathrm{CP}$ concerned provided below:

\section{Violating maxim of quantity}

Violating maxim of quantity is when people in conversations offer more or less information than is required, which thus creates humorous effects. Nevertheless, as we mentioned above, in people's daily communication, the interlocutors often offer too much or inadequate information, that is to say, it deviates from the maxims of quantity.

Example 1:

A: Why don't you study hard?

B: The more we study, the more we know. The more we know, the more we forget. The more we forget, the less we know. The less we know, the less we forget. The less we forget, the more we know. So why study?

Putting aside B's series of sentence patterns - "the more...the more..." and "the less...the less..." we can see that what B actually expresses is that study is no use. His seemingly logical remarks sound sensible at the first sight but on the second thought turn out to just be an excuse that he has found for himself. Obviously, B here offers more information deliberately than is required in A's question. And this is just how the sense of humor is embedded. 
In this case, when we consider at most utterances found in the comedy scripts, there are many violations occurred in this maxim in order to make it funny such as the speakers give the information in an exchange is not as informative as it is required, and most of them are more informative than it is required. As can be observed in the following example in bold:

(Data 1)

Ronald: Pemirsa jika anda mendapat masalah dengan yang kotorkotor, seperti piring kotor, gelas kotor, baju kotor serta pikiran kotor, silahkan anda mencuci dengan sabun cuci sanjay. Password yang harus anda ucapkan sebelum anda mencuci adalah 'bersihbersihin sanjay’.

Actually, it is impossible for dirty mind (pikiran kotor) to be washed by detergent. After observing such kind of information, the result of such kind of violation in maxim of quantity is something funny.

\section{Violating maxims of quality}

This violation means people in conversations may offer false information or offer information with not enough evidence purposely, which thus creates humorous effects. According to the maxim of quality, the interlocutors should offer the true information to others. They should not say what they believe to be false. Neither should they say that for which they lack adequate evidence. However, there are still many examples to flout the maxim of quality in the purpose to gain some special targets, using such techniques as irony, metaphor, hyperbole.

Example 2:

Diner: Waiter, there's a fly in my soup.

Waiter: Don't worry; there'll be no extra charge.

The waiter made a smart reaction to the dinner's obvious complaint at the fly. He beat around the bushes intentionally, i.e. consciously disregarding the 
actual complaint of the diner and simply following the literal meaning. But most probably his sense of humor may dissipate the initially apparent anger on the part of the diner and thus avoids an otherwise possible dispute.

The speakers in the comedy usually give the wrong information in order to create humor by violating this maxim. Consider the other example below:

(Data 2)

Ronald: Buk, anda pasti akan terkejut lagi. Maukan ibu mencuci baju ibuk yang sudah bersih ini dengan sabun sanjay. Dijamin baju ibu akan berubah menjadi baju baru. Jangan lupa passwordnya buk, 'bersih - bersihin sanjay'. Lalu masukkan baju ibuk yang sudah bersih dan tuangkan sabun sanjay ke dalam mesin ini lalu tunggu sebentar. Stop, sekarang kita buka mesin cucinya dan silahkan ibuk ambil baju yang ibu cuci.

Here the comedian gives the wrong information, and that someone does not need to rewash a clean cloth.

\section{Violating maxim of relation}

This violation is when people may offer irrelevant information deliberately. According to the maxim of relation, the interlocutors should make their contribution relevant. This maxim demands that the hearer should give answers relevant to what the speaker has said in their dialogue. The "relevant theory" includes two sides. One is under the same condition, the more situation effect, the closer relation they are; the other is under the same condition, the less efforts to handle, the more relevant they are (Sperber \&Wilson , 1986 , p125). The technique of violating the maxim of relation is obviously used in the following jokes: 
Example 5

Jay, my brother-in-law, was studying political science at U.C.L.A. one summer. Many mornings the lure of the beach won out over his obligation to attend class, until finally he realized he'd fail the course if he missed any more lectures. When Jay walked into class late, the professor interrupted his talk about folkways, customs and mores. He consulted his seating chart, then called on Jay: "Please tell the class what mores are."

Jay's sense of humor took over as he sang out, "When the moon hits your eye like a pizza pie, that's a mores are .Jay is late for school. So the professor asks him to explain what mores is. It implies that it is not a good mores always late for class. Jay violates the maxim of relation purposely and not answers correctly. But his reply tests the professor and has the sense of humor.

The maxim of relevant literally means the conversation between interlocutors is coherent. If the one is talking $\mathrm{A}$, and the other one continue with $\mathrm{B}$, their communication is unsuccessful, or it may be a humorous end.

\section{Violating maxims of manner}

That is, people may disregard the basic maxim of being perspicuous and thus creates humorous effects in their conversations. To achieve the effect of humor, the usually use technique of violating the maxim of manner is the technique of violating the maxim of avoiding ambiguity. It is also the most frequently used one of the four techniques discussed in this paper. Through ignoring the issue /topic, occasion, background, misusing or abusing the grammar of the language, all those behaviors will lead to violating of the maxim of manner is resulted in sense of humor.

Example 3

Landlor : "In a word, when are you going to pay your arrears?" 
Hard-up author: "I will satisfy your demands as soon as I receive the money which the publisher will pay me if he accepts the novel I am going to send him as soon as the work is finished which I am about to commence when I have found a suitable subject and necessary inspirations."

The deliberately disorderly sentence organization showed us a picture of a poor author who wished his promise of an unknown future remuneration were to comfort the landlord for a period of time, which sounds to us outsiders amusing but sad. The maxim of manner is different from other maxims in that it relates not to what is said but rather, to how what is said is to be said. The interlocutors should try to avoid obscurity and ambiguity when trying to pass a message. They should also try to be brief (avoid unnecessary prolixity), and the last requirement is to be orderly. This maxim requires that the conveyed meaning should be adequately clear.

\section{Discussion}

The writer chooses one of the sketches in one of these series of extravaganza TV sitcom, and then she transcribes the scripts of the sketch in the written form. After transcribing them, the writer classifies the scripts into a piece of utterances delivered by the comedians. The writer then analyzes the expressions, which considered violating on maxims of Gricean Cooperative Principles.

The title of the sketch is "Demo Sabun". In this sketch there are two comedians of extravaganza. The first is Ronald Surapraja who is acting as a detergent promotion man, and the second is Tike Priyatnakusumah who is

acting as a customer of the detergent. The setting of this sketch is in front of the house. There are two tables, on the table there is a big basket for clothes and some package of detergent that has been entitled 'SANJAY'. Next to the tables is a washing machine but it is made from a large, hard paper. 
Ronald : Pemirsa jika anda mendapat masalah dengan yang kotor-kotor, seperti piring kotor, gelas kotor, baju kotor serta pikiran kotor, silahkan anda mencuci dengan sabun cuci sanjay. Password yang harus anda ucapkan sebelum anda mencuci adalah' bersihbersihin sanjay'.

In this case, Ronald as one of the comedian in extravaganza acted as a person who is in charge of promoting a detergent which is so familiar among the female, called Sunlight. Firstly, Ronald introduces the function of this detergent for cleaning some dirty kitchen tools and house equipment, such as on plates, glasses, clothes and mind. Ronald mentions the word 'dirty mind' that can be cleaned by sunlight. In this case he has tried to violate the maxim of quantity by offering more information like in 'dirty mind'. Also he violates maxim of quality by presenting false information. Secondly, he suggested the audiences to clean it with the detergent called 'sanjay'. As we know so far that there is no detergent called 'sanjay' but 'sunlight'. Again, he violates the maxim of quality by offering false information. The third, he asks the audiences to mention the password before washing those dirty things. He introduces the password 'bersih-bersihin sanjay'. Most female has been familiar with this term introduced in the TV commercial breaks. It must be 'bersih-bersihnya sunlight'. Again he violates the maxim of quality by offering false information. As a result, the audiences will laugh at this humor because this violation is aimed at creating humorous effects.

Tike: Permisi pak, saya dapat masalah dengan baju saya kotor sekali pak, baju saya tadinya warnanya putih sekarang berubah jadi hitam. Saya minta tolong di cucikan ya pak.

In her turn, Tike acted as a customer who complains that she got a trouble with her dirty clothes. Actually the color of her cloth is white, but it turns into 
black. She asks Ronald to clean it. In this case, Tike also tries to violate the maxim of quality by offering false information. In daily life, people almost never get the problem in such a way. A white colored clothes turns into the black one. Except, the cloth falls down into the bowl of ink.

Ronald: Baik buk, silahkan langsung saja bajunya dimasukkan ke dalam mesin cuci ini lalu akan saya tuangkan sabun cuci sanjay ini ke dalamnya, dan mesinnya akan saya nyalakan. Kita tunggu sebentar saja, tidak perlu lama - lama. Sekarang kita buka ya buk dan silahkan ambil baju anda.

As a good promotion man, Ronald serves her better. He asks her to put her dirty cloth into the washing machine and he pours the powder detergent 'sanjay' into it and he turns it on. He said that it needs no longer time for doing it and then he invites her to open the washing machine and put up the cloth. In this case, Ronald violates the maxims of quality by saying "saya tuangkan sabun cuci sanjay ini ke dalamnya'. Instead of saying 'saya tuangkan sabun cuci sunlight ini ke dalamnya', so that this can create humorous effect and make people laugh by watching it.

Ronald: Buk, anda pasti akan terkejut lagi. Maukan ibu mencuci baju ibuk yang sudah bersih ini dengan sabun sanjay. Dijamin baju ibu akan berubah menjadi baju baru. Jangan lupa passwordnya buk, 'bersih - bersihin sanjay'. Lalu masukkan baju ibuk yang sudah bersih dan tuangkan sabun sanjay ke dalam mesin ini lalu tunggu sebentar. Stop, sekarang kita buka mesin cucinya dan silahkan ibuk ambil baju yang ibu cuci.

In order to make the customer is more interested in the product, Ronald told her that she will be more surprise when she washes again her already clean cloth with the 'sanjay' detergent. The cloth will turn as a new one. In this case, Ronald violates the maxims quality, by giving false information. The information given is not based on the sufficient evidence, but there is a 
reason for the comedians saying something false; make it as a humorous expression to the audience to laugh at it.

Tike: Wah, ajaib. Baju saya sekarang berubah jadi sangat baru dan dengan penampilan yang berbeda, ada bungkusnya!.

Again, Tike is so surprise because her cloth is turning new; moreover it is also covered by a good packaging. In this case, Tike violates the maxim of quality by presenting false information. The implicature is that after being washed by sanjay detergent for the second time, a very dirty cloth turns whiter and even be a new full package cloth.

Ronald: Hebat kan buk, karena sabun cuci sanjay ini mengandung ekstrak daun pepaya. Sehingga baju yang kotor bisa menjadi bersih, dicuci lagi dengan sabun sanjay baju bersih anda berubah jadi seperti baru, dan dicuci lagi dengan sabun cuci sanjay baju anda berubah jadi baju baru yang tentu saja berubah dari kaos menjadi kemeja yang masih dalam kemasan.

\section{Conclusion}

The writer investigates the scripts which ignore what is relevant to the situations in order to make them come off as flustered, odd and stupid in humorous situations. Then after transcribing the spoken data into the written data, the writer analyzes the script conversation of one of the sketches to find the pragmatic manipulation of the conversation through finding the conversational implicatures of the transcriptions and the result of this study is that based on the analysis of the pragmatic manipulation of the extravaganza comedy TV, the content of the humor is dealing with the trademark of a kind of famous product of detergent called "Sunlight" which is very popular among the housewives. 
This kind of detergent is very much useful for many things around the house. It is used to clean up the kitchen utensils, clothes or even the fruits and vegetables. People believe that wash many things using this detergent will make the things clean. As we know that the comedian also imitates the password of this detergent's TV advertisement that should be "bersih bersihnya Sunlight”, but then it is said "bersih-bersihin sanjay".

This kind of pragmatic manipulation is made to make the humor itself become more interesting and funnier so that the audiences come into the laughter. The example of the usefulness of the detergent then is manipulated

to the very fantastic result. Such as in the process of cleaning the dirty shirt become clean and purely white and the process of cleaning the already clean shirt become new clothes in a wrapped form.

The violation of maxims in conversation has a result in something funny and humorous. This kind of programs has many advantages and one of them is entertaining people.

\section{References}

Aitchison, Jean. 2003. Teach Yourself Linguistics. London: Hodder and Stroughton Educational.

Dornerus,Emma. Breaking Maxims in Conversation: A Comparative Study of How Script Writers Break Maxims in Desperate Housewives and That 70 's Show

http://ethesis.helsiki.fi/julkasut/hum/engla/pg/jaskanen/index.html

Grice, H.P. 1975. Logic and Conversation. New York: Academic Press

Levinson, Stephen C. 1983. Pragmatics. Cambridge: Cambridge University Press.

Leech, Geoffrey N. 1983. Principles of Pragmatics. USA. Longman.

Lin-Qiong, Yan. Pragmatic Interpretation and Humor Production and Comprehension. US-China Foreign Language. ISSN 15398080,USA. April 2007, Volume 5, No.4 
Parker, Frank. Ph.D. 1999. Linguistics for Non-Linguists. London. Tailor and Francis Ltd.

Situationcomedy-wikipedia, http://www.en.wikipedia.org/wiki/Situation_comedy

The Humor of Sitcoms.www.sitlec.unibo.it/ishs2002/abstract 